\title{
Obituary
}

\section{Dr Harry Aubrey Woodruff Burl}

24 September 1926 - 8 April 2020

Aubrey Burl, a name since 1976 synonymous with stone circles, passed away peacefully at his care home on 8 April, in his 94th year. He will be remembered for the remarkable contribution he made to the study of stone circles and other megalithic monuments in Britain, Ireland and northern France. He will also be remembered by many as a good friend with a wicked sense of humour. Once, upon being asked if he had been named after his antiquarian hero, John Aubrey,

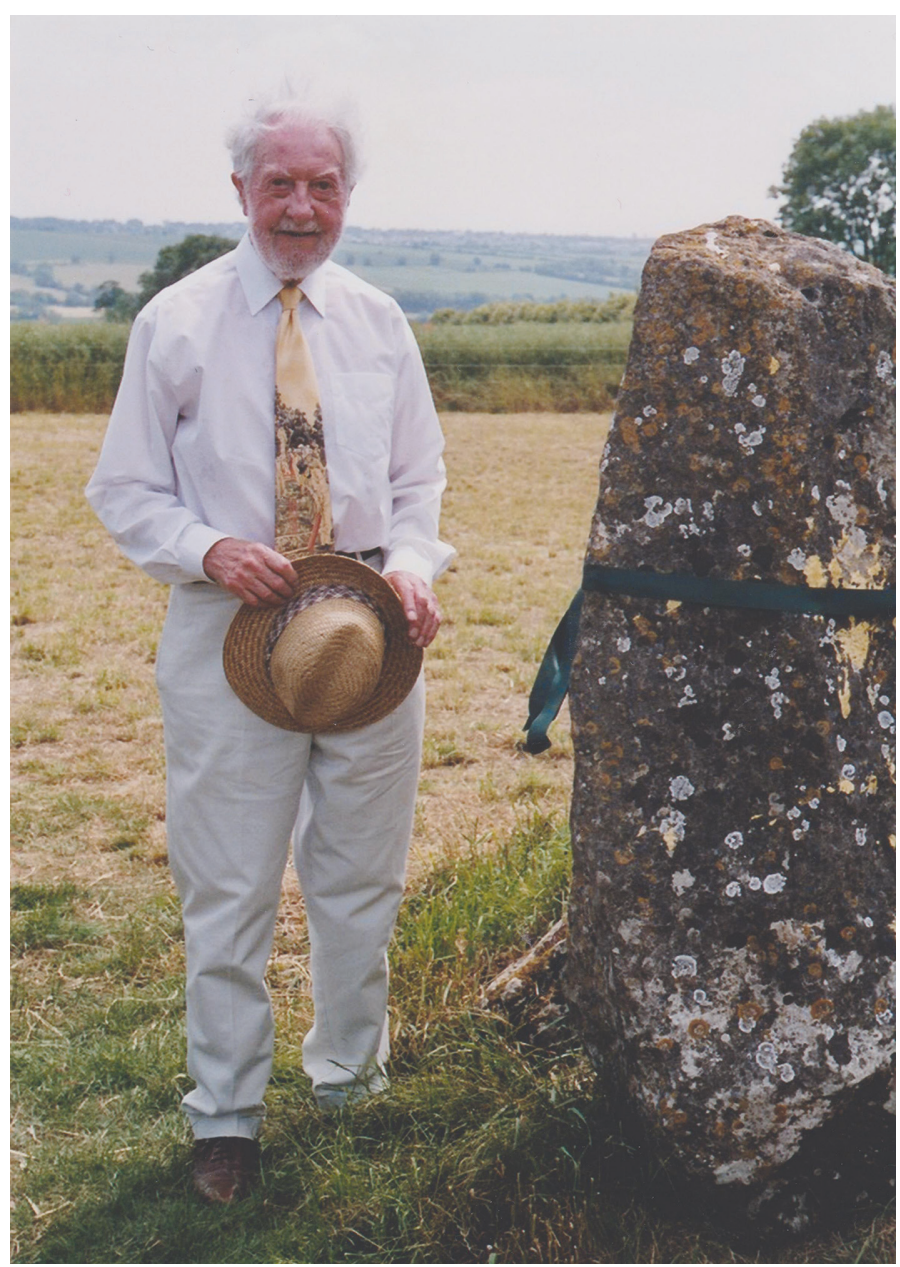

Aubrey Burl at the Rollright Stones in Oxfordshire, 19 June 2005. (C) Angela Lake) 
he replied 'No, but I would have liked to have been' and, after a pause, 'I've always liked the name John'.

Aubrey Burl, a Londoner by birth (he lived in Tottenham and remained a Spurs fan to the last), was the son of Harry Burl and his wife Lily (Wright). He served in the Royal Navy during the Second World War, during which he was wounded and of which he spoke little. On leaving the service, he studied for a BA at the University of London, before embarking on a teaching career; first Latin and then history and archaeology at Lancaster Boys' School and later, at South Wigston High School for Girls, both in Leicester. It was there that he attended a university evening class in archaeology and met Derek Simpson (who was to become a life-long friend) and with whom he discussed potential topics that he might study for an MA. The story of this meeting was one that he told many times in response to the question he was most commonly asked: 'How did you get into stone circles?' (I remember him once answering with a smile and glinting eye: 'I used the gaps between the stones'.) Aubrey often related that his first choice of study was Beakers and his second was Grooved Ware but both subjects were already being researched. His third choice, human pathology, was beyond his supervisor's ken. Having not long since visited the Rollright Stones in Oxfordshire, he asked: 'What about stone circles?' The rest is history.

Following much fieldwork and visits to the extant stone circles of Britain, Aubrey was awarded his MA at Leicester in 1970 and this formed the basis for the publication that made his name. Stone Circles of the British Isles was published by Yale University Press in 1976 and was an instant success, with a reprint the next year and two reprints the year following. In all it was reprinted seven times. This was not Aubrey's first archaeological publication. That was 'Stone circles again', in Current Archaeology for 1962, but it was with the completion of his MA that the Burl publishing machine kicked into action. 'Henges: internal features and regional groups' appeared in The Archaeological Journal for 1970 , the same date as his first publication in our Proceedings, 'The recumbent stone circles of NE Scotland' (Proc Soc Antiq Scot 102, 1973). ${ }^{1}$ During his research, Aubrey developed a fondness for Scotland and things Scottish (one of his favourite tipples was a wellknown Islay malt that he always referred to as 'Leep-frog') and his early publications reflect this fondness. As well as the aforementioned, there followed "Two "Scottish" stone circles in Northumberland' (Archaeologia Aeliana 49, 1971), 'Stone circles and ring cairns' (Scottish Archaeological Forum 4, 1972), 'The Torhouskie stone circle' (Trans D\&GNHAS, 49, 1974) and 'The early prehistoric monuments' in Hub of the Highlands published by the Inverness and District Field Club (1975).

Meanwhile, also in 1970, Aubrey left Leicester to take up the post of Principal Lecturer in Archaeology in the Department of Evolution and Prehistory, in the College of Education at Hull. This was in the hey-day of extra-mural archaeological teaching and Aubrey stayed there for a decade, until the College closed the department in 1980.

Aubrey's time at Hull was a productive one, seeing the publication of 16 articles and six books in which he demonstrated his vast knowledge and detailed research on all things megalithic. The popularity of his books was due to a number of factors. First, his style was accessible and reached an audience beyond the purely academic. Second, he was interested not just in the archaeology of the sites but their antiquarian histories and folklore. Third, his books were lavishly illustrated with stunning photographs, often taken specifically for him by well-known photographers such as Edward Piper, Fay Godwin and Mick Sharpe. Finally, his books, like his lectures, were authoritative, witty and entertaining. His introduction to Stone Circles of the British Isles begins:

To begin a book about stone circles by mentioning Stonehenge is like starting a discussion on birds by

${ }^{1}$ Editor's note: This volume of the Proceedings covered Society session 1969-70. 
talking about the Dodo. Neither is a typical example of its class. Both are above average in size, of peculiar construction, and both represent a dead-end in development.

Stone Circles was a magisterial tome and hungrily received as the number of reprints show. It brought the study of stone circles into mainstream archaeology, with a rigorous academic treatment of the subject and the compilation of the first systematic corpus and comparative study. It formed the launch-pad for many others to explore avenues of stone circle research, not always so academically rigorous, and it certainly helped fire my undergraduate interest in the Neolithic and the Bronze Age.

Following Stone Circles were, in 1979, Prehistoric Stone Circles (Shire), Rings of Stone (Frances Lincoln), Prehistoric Avebury (Yale), Megalithic Rings: Plans and Data for 229 Sites (with A \& A S Thom) (BAR) and, in 1981, Rites of the Gods (Dent). Avebury was a well-written and personal account of the archaeology and antiquarian interest in what I believe was one of his favourite stone circles. When asked at a conference: 'Do you believe that stone circles are inhabited by spirits?' He answered: 'Not at all, but I do feel slightly different inside some sites. There is an aura about Avebury that always affects me.' It proved another extremely popular book, reaching large audiences at home and especially in the USA. Rites of the Gods was a slightly more imaginative journey into presumed prehistoric religious practices and again sold in thousands.

As well as visiting and surveying megalithic sites at home and abroad during the Hull years, Aubrey was also an excavator. He undertook excavations at the Three Kings stone circle in Northumberland (with N Jones, Archaeologia Aeliana 49, 1972) but it was the Neolithic and Bronze Age sites in Scotland that particularly drew his attention. He excavated the Boghead Neolithic mound at Fochabers in 1972 and 1974 (Proc Soc Antiq Scot 114, 1984), with his then wife Margaret (O'Neil) undertaking the osteological analyses. He excavated at the Berrybrae recumbent stone circle in 1976
(Discovery and Excavation in Scotland 1976, 1977, 1978), where he was able to demonstrate that the circle had been later transformed into an enclosed cremation cemetery. In 1978-9, financed by Historic Buildings \& Monuments, Scottish Development Department, Aubrey was tasked with investigating the degree of animal damage at stone circle Sites 1 and 11 on Machrie Moor, Arran. Bad weather severely hampered the excavations, which were sealed and temporarily backfilled until excavation was continued and completed by Alison Haggarty in 1985 (Proc Soc Antiq Scot 121, 1991). In advance of plans to reconstruct the recumbent stone circle at Strichen, Aubrey undertook excavations between 1979 and 1982, financed by the American-based Earthwatch Institute, but the excavations were again completed by others and the report was compiled by Tim Phillips, Iain Hampshire-Monk and Phil Abramson (Proc Soc Antiq Scot 136, 2006).

Despite being based on his Master's thesis, many of his audience had wrongly assumed that Stone Circles sprang from doctoral research. 'A lot of people address me as Dr Burl. I don't have a doctorate so I suppose I'd better get one' he told me over a beer in a rural south Leicestershire hostelry. He subsequently submitted his literary output to the University of Leicester in support of his application for a DLitt, which he was awarded in 1984. He jokingly complained at the cost of the award because, in addition to the registration fees, all the offprints and books that he had submitted were retained by the University, so imagine his manufactured mock fury when he was awarded an honorary $\mathrm{PhD}$ by the University of Sheffield the following year!

I first met Aubrey during my time at Leicester as a $\mathrm{PhD}$ student (also supervised by Derek Simpson) but we got to know each other well during a Bronze Age Studies Group visit to Brittany in 1981. Aubrey, Derek and I had gone over a week in advance to visit some of the monuments. We were blessed with sunshine, cidre, oysters, steak frites and bonhomie. Aubrey took copious notes and photographs and (it should have come as no surprise) Megalithic Brittany: A Guide to over 350 Ancient Sites and 
Monuments (Thames \& Hudson) was published four years later. A French edition was published in 1987.

Prehistoric Astronomy and Ritual renewed Aubrey's connections with Shire (1983). The Stonehenge People (Dent) reflected his constant desire to people the past, being always passionately aware that sites and monuments were conceived, built and used by real people to whom the monuments were more than just rings of stone. A study of Four Posters (BAR) was published in 1988 and Stone Rows and Standing Stones: Britain, Ireland and Brittany (with A \& A S Thom) (BAR 2 vols) followed in 1990. Prehistoric Henges (Shire) was published in 1991 and there were further collaborations with Yale. From Carnac to Callanish: The Prehistoric Stone Rows and Avenues of Britain, Ireland and Brittany was published in 1993; A Guide to the Stone Circles of Britain, Ireland and Brittany and Great Stone Circles were both published in 1995.

Aubrey embarked on the mammoth task of updating and augmenting Stone Circles to include his work in Brittany that was published in 2000 as The Stone Circles of Britain, Ireland and Brittany, purposefully to mark the millennium. Whilst working on these revisions, he often suggested that this would be his final contribution to the world of megalithic studies. His letter that accompanied my gift copy said: 'And now I shall retire' (he was 75). He did not. Stukeley's Stonehenge (with Neil Mortimer, Yale) followed in 2005, Stonehenge. A New History of the World's Greatest Stone Circle (Constable) in 2006 and John Aubrey and Stone Circles (Amberley) in 2010. Stonehenge: A New History was a personal but controversial book and Aubrey knew it. His covering letter reads: 'Am awaiting archaeological reaction - if any. The Establishment will not like what I have written ... But, like great empires, Establishments crumble. Be that as it will be, I do hope that you like at least bits of the book.'

At this time in his career, Aubrey drifted away from prehistory turning more to literary and historical subjects, reflecting his earlier years. He did not abandon archaeology, as has been already demonstrated, but certainly his active interest declined. His biography of the 18th-century Welsh pirate (Barty Du - Black Bart) was published as That Great Pyrate: Bartholomew Roberts and His Crew 17181723 in 1997 (Alun Books) and reappeared in a slightly different format in 2006 (Sutton). This was actually Aubrey's first book, written around 1955, but it failed to find a publisher at the time. In 2000, Danse Macabre (Sutton) was a gripping history of the lyric poetry and underworld dealings of the 15th-century French poet François Villon. Another favourite poet, reflecting his classical education, Catullus, was a focus of a 2004 'biography' Catullus: A Poet in the Rome of Julius Caesar (Constable). I use biography in inverted commas as little factual is known of the life of Catullus and much has to be gleaned, inferred and imagined from his poems. Indeed, in his review in the Guardian, John Buchan wrote: 'Aubrey Burl's spirited Catullus is the latest attempt to write an entire romantic biography of the poet out of supposition. Since there aren't any facts, he supplies their absence with conjecture, much of it quite convincing.' Some of the poems were translated by Aubrey himself, others by Humphrey Lucas.

Returning to French medieval history, God's Heretics: The Albigensian Crusade (Sutton, 2002) was an account of the brutal annihilation of the Cathars of the Languedoc and he returned to a related subject in Courts of Love, Castles of Hate: Troubadours and Trobairitz in Southern France, 1071-1321 (History Press, 2008). Aubrey's final book, again taking one of his favourite poets as the subject, was Shakespeare's Lover; The Mystery of the Dark Lady Revealed (Amberley, 2014) and was published in his 90th year.

An energetic and enthusiastic researcher, it was obvious that Aubrey loved writing and even personal letters frequently exceeded two typed pages of A4. He possessed considerable skill in the art and this clearly shows in his books as he steered a steady path between the academic and popular. My favourite quote from his works (Prehistoric Henges, Shire, 1991) refers to the henge at Muir of Ord - which has now been levelled for a green on the Muir of Ord golf course. Aubrey wrote: 
As the players engage in the ritual of depositing a chalky white ball into a hole carefully positioned inside the henge, one wonders if they sense faint mocking laughter somewhere on the green.

He engaged with local societies and interested leity as readily as with high-ranking academics. His lectures were delivered with humour, insight and in a relaxed manner and he was at home with his audiences who ranged from small local societies to the Smithsonian Institute (visited as part of a lecturing tour of the USA following the publication of Stone Circles). He had open and frank discussions with ley-liners, neo-pagans, archaeo-geometricians and archaeo-astronomers, and though he rarely agreed with them, he engaged with them and politely listened to them as they listened to him. Regarding the work of Alexander and Archie Thom, Aubrey commented: 'I thank God for the work of the Thoms though I disagree with almost everything they've written.' Nevertheless, he collaborated with them and maintained a long-lasting friendship. He critically considered the theories regarding standardised measurement and the Megalithic Yard, preferring instead naturally varying body measurements. He treated archaeo-astronomy in a similar way and was prepared to accept (and indeed embrace) orientation of sites on the rising and setting of major heavenly bodies - but not on obscure stars. He influenced many young artists and musicians and he allowed the website The Megalithic Portal to publish online his gazetteer of circles and rows.

In many ways, despite his public appearances, Aubrey was a rather private man, almost shy. He preferred to talk about Shakespeare, cricket and even stone circles than about himself. His move to Birmingham, following the closure of Hull, gave him not just access to a university library, but also opportunities to lead study tours and engage in extra-mural teaching. It also provided ease of travel around the UK and beyond, a proximity to Edgbaston cricket ground and, of course, he was within striking distance of Stratford-onAvon, where he could use his RSC membership to indulge his love of Shakespeare and theatre in general. He was excellent company, being an accomplished raconteur with a vibrant sense of humour and an infectious, slightly chortling, shoulder-shaking laugh. He will be missed by the archaeological community but more especially by those privileged to call him a friend.

Times, of course, change and research continues to push forward so that some of the theories that Aubrey suggested can be questioned or have even been disproved. Some of his books were criticised at the time for using selective data, for being over-imaginative or for being overinterpretive. The discovery of quarries in west Wales has now quashed his long-held conviction that the Bluestones at Stonehenge were locally sourced glacial erratics and he (somewhat grudgingly) accepted this when we last met. But this is not to deny the rich legacy that he leaves, not just in his academic research, his books and his articles, but in the number of people to whom he reached out and influenced.

Aubrey was elected FSAScot in 1971 having been proposed by that equally energetic fieldworker Audrey Henshall. He became an FSA in 1981 and served as Meetings Secretary of the Prehistoric Society between 1983-8. He was presented with a Festschrift, Prehistoric Ritual and Religion (Sutton) at a dinner attended by contributors and friends in Birmingham in 1998 and he received his Honorary FSASCOT in 2000, an honour which he greatly valued. Aubrey married the artist Olwen Hughes, with whom he had a son, Christopher; then Margaret O'Neil, a lecturer in physiotherapy, with whom he had a son, Geoffrey. His first wife and both sons pre-deceased him. He leaves a widow, Judith (Lawson) whom he married in 1985.

Alex Gibson 